\title{
Comparative achene morphology of Persicaria sect. Cephalophilon and related taxa (Polygonaceae)
}

\author{
Min-Jung KONG and Suk-Pyo HONG* \\ Laboratory of Plant Systematics, Department of Biology, Kyung Hee University, Seoul 02447, Korea \\ (Received 4 June 2018; Revised 22 June 2018; Accepted 27 June 2018)
}

\begin{abstract}
The achene morphology of 21 taxa of Persicaria sect. Cephalophilon including the related taxa of Koenigia (Polygonaceae) was examined using stereo microscopy and scanning electron microscopy to evaluate its diagnostic values and taxonomic implications. The outlines of achene were narrowly ovoid to broadly ovoid in general, and elliptic achenes were observed in Koenigia taxa, with the achene shape being biconvex or trigonous. The size of the $P$. sect. Cephalophilon taxa ranged from $0.93-3.55 \times 0.80-2.31 \mathrm{~mm}$ and the size of examined Koenigia taxa ranged from 1.10-1.84 $\times 0.79-1.02 \mathrm{~mm}$. The smallest achenes in $P$. sect. Cephalophilon were observed in $P$. humilis and the largest achenes were found in $P$. chinensis var. chinensis. Furthermore, infraspecific taxa of $P$. chinensis had relatively large achenes compared to other taxa within the section. Most taxa of P. sect. Cephalophilon had dull achenes, while four taxa had glossy achenes (P. capitata, P. runcinata var. runcinata, $P$. runcinata var. sinensis, and $P$. sinuata). Four types of surface patterns (smooth, tubercles, small pits, and irregular ridge) were observed, and the tubercles were divided into two subtypes according to the grouping and distribution pattern. The achene morphology of $P$. sect. Cephalophilon is described and compared, and its taxonomic implications are also discussed.
\end{abstract}

Keywords: achene morphology, micromorphology, SEM, pericarp, Persicaria section Cephalophilon

Persicaria (L.) Mill., a genus within the tribe Persicarieae Dumort., consists of approximate 100 species. It is characterized by many-flowered spicate, capitate or panicle inflorescence, a simple leaf, chartaceous ochrea entire or ciliate, 4-5 tepals, and 4-8 stamens (Haraldson, 1978; Freeman and Reveal, 2005). Persicaria has often been suggested as a member of Polygonum L. s.l. (Li et al., 1998, 2003; Zhu et al., 2007), while various morphological and molecular data support the independence of the genus Persicaria from Polygonum s.l. based on the inflorescence, ochrea type, tepal venation, or filament shape (Haraldson, 1978; Ronse Decraene and Akeroyd, 1988; Ronse Decraene et al., 2000; Lamb Frye and Kron, 2003).

Persicaria are divided into four to five sections based on the presence of an exerted style and prickles, the type of inflorescence, and the degree of tepal connation (sections Echinocaulon, Cephalophilon, Persicaria, Tovara, and Rubrivena) (Freeman and Reveal, 2005). P. sect.
Cephalophilon (Meisn.) H. Gross, consisting of 19 taxa (12 species 7 varieties) of herbaceous plants, is distinguished from other sections within Persicaria by a petiole usually winged, stem without prickles and inflorescence capitate (Meisner, 1832; Li et al., 2003; Freeman and Reveal, 2005). These morphological features have supported this section since it was initially suggested as a single section within Polygonum by Meisner (1832) (Haraldson, 1978; Li et al., 1998, 2003; Freeman and Reveal, 2005). Moreover, $P$. sect. Cephalophilon is also a monophyletic group based on highly supported values according to recent molecular studies (Kim and Donoghue, 2008; Galasso et al., 2009; Schuster et al., 2015). P. sect. Cephalophilon is sister to the rest of sections in Persicaria, and the Persicaria which include section Cephalophilon altogether is sister to AKB clade (Aconogonon - Koenigia - Bistorta clade); thus, a detailed study of $P$. sect. Cephalophilon would enhance our understanding of the relationships among these taxa.

\footnotetext{
*Author for correspondence: sphong@khu.ac.kr
} 
Nonetheless, the sectional delimitation and infrasectional classification of $P$. sect. Cephalophilon have remained unclear. In the earliest treatments, some taxa (P. capitata (Buch.-Ham. ex D. Don) H. Gross, P. microcephala (D. Don) H. Gross and P. runcinata (Buch.-Ham. ex D. Don) H. Gross) belonged to Polygonum sect. Polygonum (Don, 1825), and P. sect. Cephalophilon was treated as a genus Cephalophilon (Meisn.) Spach, Ampelygonum Lindl. or Truellum Houtt. (Lindley, 1838; Spach, 1841; Sojak, 1974). In addition, some taxa of Koenigia belonged to $P$. sect. Cephalophilon due to the floral characters (e.g., inflorescence, tepal, and style) (Li et al., 1998, 2003), although various morphological characters have indicated that these taxa $(P$. sect. Cephalophilon and Koenigia) were separated (Haraldson, 1978; Hedberg, 1997; Ronse Decraene et al., 2000). Meisner (1832) suggested two subsections, Didymocephalon and Corymbocephalon, to be included in the Polygonum sect. Cephalophilon, but more detailed research to evaluate the infrasectional classification has not been conducted. Subsequently, Zhu et al. (2007) also suggested new series (Palmatifolia, Perennes, Criopolitana, and Annui) within Polygonum sect. Cephalophilon based on the habit and stomata type on the abaxial side of the leaf. It is noteworthy that this suggestion still includes some Koenigia taxa. Therefore, more detailed study of Persicaria sect. Cephalophilon is necessary to re-evaluate the suggested infrasectional classification.

Fruit and seed morphology have provided useful characters to identify in the flowering plants, and especially, the surface sculpturing and ornamentation have been considered to have systematic importance (Roth 1977; Olowokudejo, 1985; Barthlott, 1990; Zhang et al., 2005). Achene morphologies have been studied by many researchers within Polygonaceae Juss. (Martin, 1954; Oh and Hong, 1999; Ayodele and Zhou, 2010; Ghimire et al., 2016; Kanwal et al., 2016), and the achene micromorphology and anatomy have already been described as useful taxonomic features in certain sectional and generic delimitations (Ronse Decraene et al., 2000). Although the detailed achene morphology of $P$. sect. Cephalophilon has been studied (e.g., P. capitatum, P. chinensis, P. nepalensis or $P$. runcinata) (Ronse Decraene et al., 2000; Kantachot et al., 2010; Ghimire et al., 2016; Kanwal et al., 2016), the papers were limited to only certain taxa. In addition, a comprehensive achene morphological study of $P$. sect. Cephalophilon is still lacking despite the character has been used in many systematic studies.

Thus, the present study aims (1) to document and illustrate the achene morphology of $P$. sect. Cephalophilon and (2) to evaluate the systematic values of the obtained achene characteristics of $P$. sect. Cephalophilon.

\section{Materials and Methods}

The achene morphologies of 17 taxa of $P$. sect. Cephalophilon except two taxa ( $P$. criopolitana and $P$. umbrosa) and related taxa whose positions are unclear between this section and Koenigia (Table 1, Appendix 1) were investigated. The achenes were collected from herbarium specimens of K, KHUS, KUN, PE, and WU (Thiers, 2018).

Fully matured fruits were selected and observed under a stereomicroscope (SteREO Discovery.V8, Carl Zeiss Microscopy GmbH, Jena, Germany). To observe the detailed sculpturing patterns of achenes, dry fruits were rehydrated overnight in the Agepon wetting agent (Agepon:DW = 1:200) and fresh fruits were fixed in FAA (formaldehyde: acetic acid: alcohol) for $24 \mathrm{~h}$ and stored in $70 \%$ ethanol. The prepared achenes were dehydrated through an ethanol series (in 50, 70, 90 , and $95 \%$ ethanol for $10 \mathrm{~min}$ each and in absolute ethanol for about $20 \mathrm{~min}$ ) after which the absolute acetone was replaced with carbon dioxide to reach the critical point drying (SPI$13200 J-A B$, SPI Supplies, West Chester, PA, USA). All samples for the scanning electron microscopy (SEM) analysis were coated with platinum using an ion-sputtering device (E-1045, Hitachi, Tokyo, Japan). The samples were examined under a field emission SEM (FE-SEM, S-4700, Hitachi) device operating at $10 \mathrm{kV}$ with a working distance of $10-13 \mathrm{~mm}$. For the achene length and width 5-10 samples per specimen of each taxon were measured using software (Macnification 2.0 version, Orbicule, Leuven, Belgium). To confirm the consistency of morphological characteristics, we compared at least two specimens for each taxon when possible. Only one achene each of $P$. chinensis var. paradoxa 1, P. glacialis var. glacialis 3, P. microcephala var. microcephala, $P$. strindbergii was included for the comparison between taxa. The terminology for fruit characters was mainly adopted from Ronse Decraene et al. (2000).

\section{Results and Discussion}

\section{External morphs: size, color and shape}

The size of the achenes ranged from 0.93 to $3.55 \mathrm{~mm}$ in length and from 0.79 to $2.31 \mathrm{~mm}$ in width (Table 1). The achene size and shape were similar to those recorded in previous studies (Ronse Decraene et al., 2000; Kantachot and Chantaranothai, 2011; Ghimire et al., 2016; Kanwal et al., 2016). The largest achenes were found in $P$. chinensis var. chinensis $(3.28-3.41 \times 2.30-2.31 \mathrm{~mm}$; investigated specimen, Togash 533), while the smallest achenes of $P$. sect. Cephalophilon were found in P. humilis $(0.93-1.08 \times 0.80$ $1.01 \mathrm{~mm}$; investigated specimen, Peng et al. 9347). Among 
the studied taxa, the $P$. chinensis group has the largest achene in the section $(2.34-3.55 \times 1.77-2.31 \mathrm{~mm})$, and relatively large achenes are also observed in $P$. microcephala var. sphaerocephala and $P$. strindbergii. The sizes of the Koenigia taxa were 1.10-1.84 × 0.79-1.02 mm (Table 1). The Koenigia achenes are smaller than those of $P$. sect. Cephalophilon, while the almost taxa within the section have similar achenes size except for the smallest or the largest achenes.

Table 1. Details of achene characteristics in Persicaria sect. Cephalophilon and related taxa within the Koenigia.

\begin{tabular}{|c|c|c|c|c|c|c|c|c|c|}
\hline Taxa & Length (mm) & Width (mm) & Outline & Shape & Beak & Stipitate & Glossy & $\overline{\mathrm{ST}}$ & Figure \\
\hline P. capitata 1 & $1.99-2.13$ & $1.20-1.32$ & nov & tri & + & + & + & I & $1 \mathrm{~A}, 2 \mathrm{~A}$ \\
\hline P. capitata 2 & $1.54-1.60$ & $0.96-0.98$ & nov & tri & + & + & + & $\mathrm{I}$ & - \\
\hline P. capitata 3 & $1.72-1.78$ & $0.88-1.10$ & nov & tri & + & + & + & I & - \\
\hline P. capitata 4 & $1.64-1.78$ & $0.91-0.97$ & nov & tri & + & + & + & I & - \\
\hline P. chinensis var. chinensis 1 & $3.28-3.41$ & $2.30-2.31$ & ovo & $\operatorname{tri}$ & + & + & - & $\mathrm{II}-2$ & $1 \mathrm{~B}, 2 \mathrm{~B}$ \\
\hline P. chinensis var. chinensis 2 & $2.57-2.70$ & $1.99-2.17$ & bov & tri & + & + & - & II-2 & - \\
\hline P. chinensis var. hispida 1 & $2.72-2.73$ & $1.95-2.01$ & ovo & tri & + & + & - & $\mathrm{II}-2$ & - \\
\hline P. chinensis var. hispida 2 & $2.34-2.73$ & $1.77-1.92$ & ovo & tri & + & + & - & II -2 & $1 \mathrm{C}$ \\
\hline P. chinensis var. ovalifolia & $2.46-2.86$ & $1.78-2.02$ & ovo & tri & + & + & - & II-2 & $1 \mathrm{D}$ \\
\hline P. chinensis var. paradoxa 1 & 2.42 & 1.87 & bov & tri & + & + & - & II-2 & - \\
\hline P. chinensis var. paradoxa 2 & $2.89-3.55$ & $2.08-2.18$ & ovo & tri & + & + & - & II-2 & $1 \mathrm{E}, 2 \mathrm{C}$ \\
\hline P. glacialis var. glacialis 1 & $1.30-1.31$ & $0.96-0.97$ & ovo & tri & + & + & - & II-1 & $1 \mathrm{~F}$ \\
\hline P. glacialis var. glacialis 2 & $1.59-1.68$ & $1.25-1.32$ & bov & $\operatorname{tri}$ & + & + & - & II-1 & - \\
\hline P. glacialis var. glacialis 3 & 1.27 & 0.85 & nov & tri & + & + & - & II-1 & - \\
\hline P. glacialis var. przewalskii 1 & $1.77-1.86$ & $1.55-1.83$ & bov & tri & + & $-/+$ & - & II-1 & $1 \mathrm{G}, 2 \mathrm{D}$ \\
\hline P. glacialis var. przewalskii 2 & $1.82-2.02$ & $1.61-2.00$ & bov & $\operatorname{tri}$ & + & + & - & II-1 & - \\
\hline P. humilis 1 & $1.03-1.15$ & $0.87-0.97$ & bov & bic & + & + & - & IV & $1 \mathrm{H}, 2 \mathrm{E}$ \\
\hline P. humilis 2 & $1.13-1.15$ & $1.03-1.04$ & bov & bic & + & + & - & IV & - \\
\hline P. humilis 3 & $0.93-1.08$ & $0.80-1.01$ & bov & bic & + & + & - & IV & - \\
\hline P. microcephala var. microcephala & 1.81 & 1.13 & nov & tri & + & + & - & II -2 & $1 \mathrm{I}, 2 \mathrm{~F}$ \\
\hline P. microcephala var. sphaerocephala & $3.15-3.28$ & $2.25-2.27$ & ovo & tri & + & + & - & II -2 & - \\
\hline P. microcephala var. wallichii & $2.07-2.10$ & $1.23-1.30$ & nov & $\operatorname{tri}$ & + & + & - & II -2 & $1 \mathrm{~J}$ \\
\hline P. nepalensis 1 & $2.11-2.33$ & $1.86-2.04$ & bov & bic & + & + & - & II-1, IV & $1 \mathrm{~K}, 2 \mathrm{G}$ \\
\hline P. nepalensis 2 & $1.91-1.95$ & $1.50-1.58$ & bov & bic & + & + & - & II-1 & - \\
\hline P. nepalensis 3 & $2.23-2.27$ & $1.80-1.82$ & bov & bic & + & + & - & II-1 & - \\
\hline P. palmata & $2.17-2.71$ & $1.50-1.88$ & bov & tri & + & + & - & II-1 & $1 \mathrm{~L}, 2 \mathrm{H}$ \\
\hline P. runcinata var. runcinata & $2.47-2.50$ & $1.22-1.38$ & nov & tri & + & + & + & III & $1 \mathrm{M}, 2 \mathrm{I}$ \\
\hline P. runcinata var. sinensis & $1.80-1.97$ & $1.54-1.59$ & bov & $\operatorname{tri}$ & - & + & + & I, III & $1 \mathrm{~N}, 2 \mathrm{~J}$ \\
\hline P. sinuata & $1.32-1.97$ & $1.01-1.37$ & bov & $\operatorname{tri}$ & + & + & + & I, III & 10 \\
\hline P. strindbergii & 2.79 & 1.78 & ovo & tri & + & + & - & IV & $1 \mathrm{P}$ \\
\hline K. delicatula & $1.62-1.75$ & $0.79-0.96$ & ell & tri & - & - & - & I & $1 \mathrm{Q}, 2 \mathrm{~K}$ \\
\hline K. nepalensis 1 & $1.33-1.84$ & $0.80-1.02$ & ell & tri & - & $-/+$ & - & I & - \\
\hline$K$. nepalensis 2 & $1.35-1.67$ & $0.83-1.01$ & ell & tri & - & - & - & I & $1 \mathrm{R}$ \\
\hline K. pilosa & $1.31-1.45$ & $0.80-1.01$ & bov & tri & - & + & - & I & $1 \mathrm{~S}$ \\
\hline K. islandica & $1.10-1.33$ & $0.84-1.01$ & ovo & bic & - & - & - & I & $1 \mathrm{~T}, 2 \mathrm{~L}$ \\
\hline
\end{tabular}

ST, surface sculpture; bov, broadly ovoid; bic, biconvex; ell, elliptic; nov, narrowly ovoid; ovo, ovoid; tri, trigonous; +, present; -, absent. 


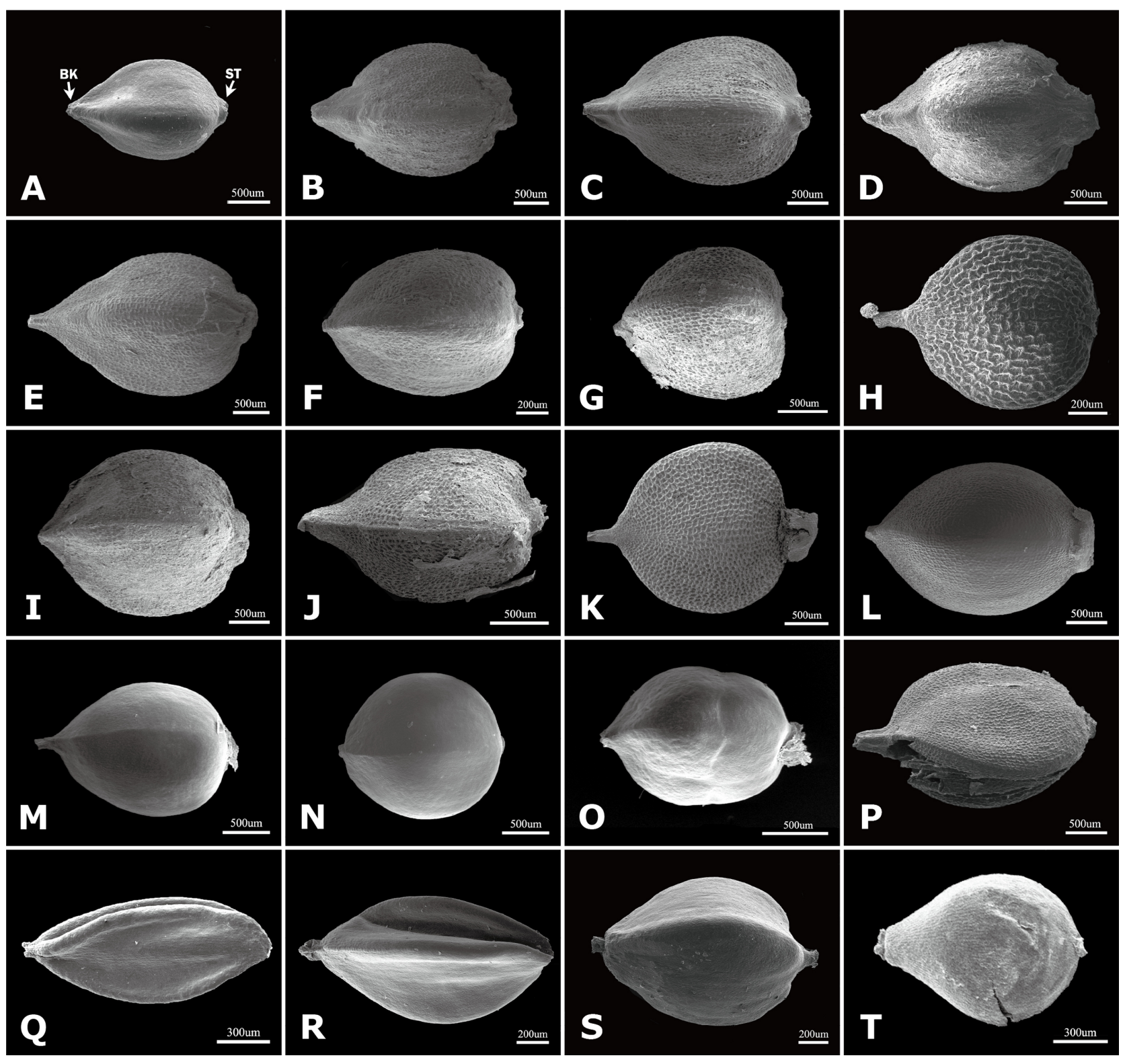

Fig. 1. Scanning electron microscopy micrographs of the achenes of section Cephalophilon and taxa related to Koenigia. A. Persicaria capitata (Expedition to Sichuan 268). B. P. chinensis var. chinensis (Togash 533). C. P. chinensis var. hispida (Zhou et al. 017). D. P. chinensis var. ovalifolia (Iwatsuki et al. S1493). E. P. chinensis var paradoxa (Li et al. 1192). F. P. glacialis var. glacialis (Wang 69071). G. P. glacialis var. przewalskii (Xiao 738). H. P. humilis (Gamble s.n.). I. P. microcephala var microcephala (Grierson and Long 3874). J. P. microcephala var. wallichii (Qinghai-Xizang Expedition 6676). K. P. nepalensis (Kong 7). L. P. palmata (Wang 79687). M. P. runcinata var. runcinata (Johns et al. 9642). N. P. runcinata var. sinensis (Li and Huang 2849). O. P. sinuata (Strachey and Winterbottom 40). P. P. strindbergii (Henry 10499A). Q. K. delicatula (Wang 68561). R. K. nepalensis (Sinclair and Long 5041). S. K. pilosa (Zhao 259). T. K. islandica (no detailed collect information). BK, beak; ST, stipitate.

The achenes in this study are brown to black, and noticeable colors such as green or yellow were not found in the present study. In $P$. sect. Cephalophilon, the achenes of most taxa were partially enclosed by the perianth, while $P$. chinensis has an accrescent perianth, such as a perianth being berry-like in appearance (Li et al., 2003; Ghimire et al., 2016). This perianth makes it easy to distinguish $P$. chinensis from the other taxa of $P$. sect. Cephalophilon. Most taxa had dull achenes, while four taxa had glossy achenes ( $P$. capitata, $P$. runcinata var. runcinata, $P$. runcinata var. sinensis, and $P$. sinuata). Thus, the presence of glossiness with other achene characters can be helpful to identify certain taxa. 
The outlines of achenes were found to be elliptic to broadly ovoid (Fig. 1), and the most taxa have ovoid achenes. The taxa of $P$. sect. Cephalophilon had narrowly ovoid to broadly ovoid achenes (Fig. 1A-P, S, T), while elliptic achenes were found in Koenigia (Fig. 1Q-R). Elliptic achenes with both ends narrow are observed in $K$. delicatula and $K$. nepalensis. The achene shapes in the studied taxa were trigonous or biconvex (Fig. 1, Table 1). Most taxa had trigonous achenes, while biconvex achenes were observed in P. humilis, P. nepalensis, and $K$. islandica. These taxa, which had biconvex achenes, are clearly distinguished from other taxa. The achene dimorphism in the shape is often found in many taxa in Polygonaceae, as well as in Polygonum s.l. (Yurtseva, 2001; Li et al., 2003; Freeman and Reveal, 2005; Kantachot and Chantaranothai, 2011). In P. sect. Cephalophilon, P. glacialis var. przewalskii is known to have heteromorphic achenes (e.g., biconvex or trigonous) (Li et al., 2003); however, the achene shapes were rather consistent for the taxa in this study. Therefore, the achene shape can be used when setting limits on certain taxa.

The existence of a beak, which is positioned at style base, was also an investigated character. All taxa of $P$. sect. Cephalophilon had a beak structure on the apex (Fig. 1A-M, O, P), except for P. runcinata var. sinensis (Fig. 1N), while the Koenigia taxa had achenes without a beak (Fig. 1Q-T). A stipitate was also observed in most of the taxa studied here, except some Koenigia taxa (Table 1).

\section{Achene micromorphology: surface sculpturing}

Four types of achene surfaces were recognized: smooth (Type I), tubercles (type II), small pitted (Type III), and irregularly ridged (Type IV), and the tubercles were divided into two subtypes according to the grouping and distribution pattern (Fig. 2, Table 1). The surface sculpture type is consistent with each taxa except $P$. nepalensis (Type II-1 and IV), $P$. runcinata var. sinensis (Type I and III), and P. sinuata (Type I and III) (Table 1).

\section{Type I}

The whole fruit surface is smooth (Fig. 2A, K, L). The surface is uneven and anticlinal cell walls were observed; however, characterized structures such as tubercles were not observed: P. capitata, P. microcephala var. microcephala, $P$. runcinata var. sinensis, $P$. sinuata, $K$. delicatula, $K$. nepalensis, $K$. pilosa, and $K$. islandica.

\section{Type II}

Tubercles are distributed on the achene surface. This type is divided into two subtypes based on the grouping and distributed pattern.

\section{2a. Type II-1}

Tubercles are distributed along the anticlinal wall singly (discontinued), and the anticlinal wall forms a complete reticulate (Fig. 2D, G, H): $P$. glacialis var. glacialis, $P$. glacialis var. przewalskii, P. nepalensis, and P. palmata.

\section{2b. Type II-2}

Numerous tubercles are distributed along the reticulated anticlinal wall. Connected or fused tubercles are also observed, and single tubercles are occasionally observed on the lumen surface (Fig. 2B, C, F): P. chinensis var. chinensis, P. chinensis var. hispidum, $P$. chinensis var. ovalifolia, P. chinensis var. paradoxa, . microcephala var. microcephala, P. microcephala var. sphaerocephala, and P. microcephala var. wallichii.

\section{Type III}

The achene surface with small pits is laying radially around the cell (Fig. 2I, J): P. runcinata var. runcinata, P. runcinata var. sinensis, and $P$. sinuata.

\section{Type IV}

Irregular ridges are laying on anticlinal cell walls, creating a reticulate pattern. This reticulate pattern is similar to that of Type II, however, tubercles were not observed on the ridge (Fig. 2E): P. humilis, $P$. nepalensis (partial), and $P$. strindbergii.

The anticlinal cell type on achene surface of $P$. sect. Cephalophilon are either undulate or straight-curved (Fig. 2). The anticlinal cell wall was difficult to observe on a Type I surface (Fig. 2A); however, Koenigia taxa, which have Type I surfaces, show easily distinguishable anticlinal cell walls (Fig. $2 \mathrm{~K}$, L, Table 1). The anticlinal cell walls of Koenigia are puzzle-like arrangement of undulate anticlinal walls (Fig. 2K, L, Table 1), but $K$. islandica has relatively weak undulated anticlinal cell walls (Fig. 2L). The remarkable anticlinal walls of achene surface with the absence of a beak is also help to clarify Koenigia taxa from $P$. sect. Cephalophilon. The Koenigia has been considered related taxa with Aconogonon, which was treated as a section of Koenigia, based on molecular phylogeny (Schuster et al., 2015). The Aconogonon is known to have ovate or ellipsoid achenes with smooth surface, and moreover, beak and stipitate are also found (Hong, 1992). Thus, achenes outline and surface sculpture of these two group are similar, but absence of beak is distinguished Koenigia taxa from Aconogonon.

Most of taxa in present study have Type II surface (11 taxa) (Fig. 2B-D, F-H, Table 1), and Type II-2 is more abundant 

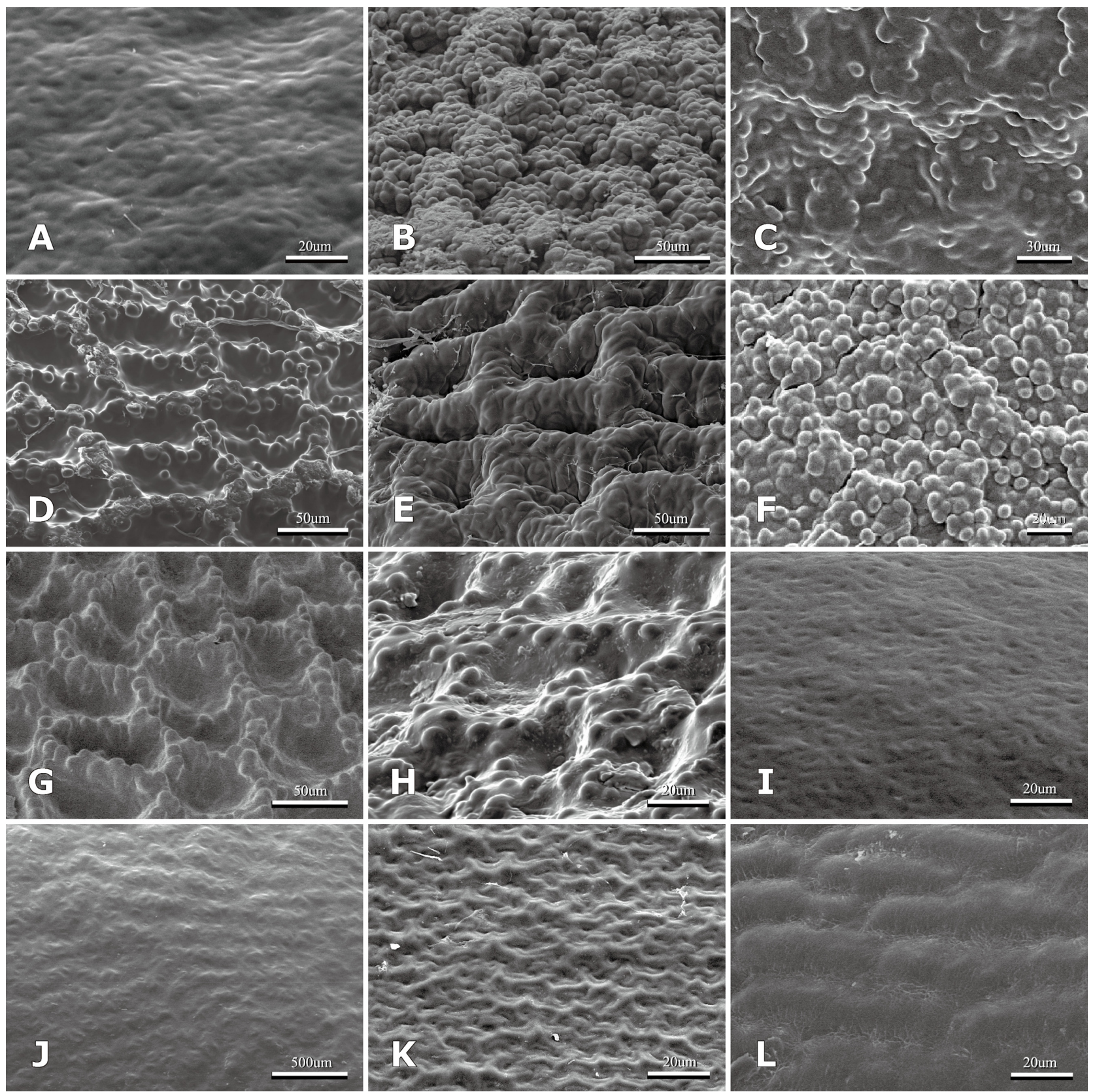

Fig. 2. The surface of the achene of section Cephalophilon and taxa related to Koenigia. A. Persicaria capitata (Type I; Expedition to Sichuan 268). B. P. chinensis var. chinensis (Type II-2; Togash 533). C. P. chinensis var. paradoxa (Type II-2; Li et al. 1192). D. P. glacialis var. przewalskii (Type II-1; Xiao 738). E. P. humilis (Type IV; Gamble s.n.). F. P. microcephala var. microcephala (Type II-2; Grierson and Long 3874). G. P. nepalensis (Type II-1; Kong 7). H. P. palmata (Type II-1; Wang 79687). I. P. runcinata var. runcinata (Type III; Johns et al. 9642 ). J. P. runcinata var. sinensis (Type III; Li and Huang 2849). K. K. delicatula (Type I; Wang 68561). L. K. islandica (Type I; no detailed collect information).

among taxa. Type II-1 is observed in four taxa, $P$. glacialis var. glacialis, P. glacialis var. przewalskii, P. nepalensis, and $P$. palmata. Among these taxa, P. nepalensis could be distinguished from other taxa based on biconvex and Type II1 surfaces achene although part of surface has Type IV. The existence of tubercles in achene micromorphology is considered to be an important feature. The functions of tubercles are not clear, but a protruding structure, such as tubercles or verrucae, may be related to the habitat environment or the dispersal mechanisms (Oh and Hong, 1999; Yurtseva, 
2001; Kantachot and Chantaranothai, 2011). For example, Oh and Hong (1999) suggested that an achene with tubercles had a more developed morph than a smooth achene; thus, an achene with tubercles is motivating modifications to reach a better fit with the possibilities of myrmecochory or zoochory. On the other hand, this structure is generally found on the achene surfaces of plants in arid habitats and thus may serve to absorb water for germination and/or help to move water to the inside of the cells (Yurtseva, 2001; Kantachot and Chantaranothai, 2011). However, the $P$. sect. Cephalophilon taxa have similar habitat environments; moreover, this feature is consistent in each species (e.g., mountain slopes, grassy slopes, shaded places, thickets in valleys) (Li et al., 2003; Freeman and Reveal, 2005).

Types III and IV represent useful features by which to classify certain species of the $P$. sect. Cephalophilon. The small pits of Type III appeared to be scattered throughout the surface, and this type is observed in the intra-species taxa of $P$. runcinata and $P$. sinuata in the present study (Table 1). The $P$. sinuata has been considered to be close relationship with $P$. runcinata based on its morphology (Babington, 1838), and surface micromorphogy of achene is supported this suggestion. However, these two taxa were belonged to different series (e.g., series Annui and Perennes) according to infrasectional classification proposed by Zhu et al. (2007), thus more study is needed to clarify the taxonomic relationship between two taxa.

Type IV is observed in $P$. humilis, $P$. strindbergii, and a small portion of $P$. nepalensis. Among these taxa, $P$. humilis is easily distinguished from the others based on achene size and shape with surface sculpturing. Though the $P$. humilis and $P$. neplensis have similar achene morph (Fig. 1H, K), there are differences of size and micromorphology. These two taxa are known to have similar gross morphologies as well as achene morphs, indicating that a detailed phylogenetic study of these two taxa is needed.

In conclusion, a systematic evaluation of the achene morphology of $P$. sect. Cephalophilon revealed that a comprehensive approach of studied characters, such as the size, shape, and sculpturing type, is useful for identifying certain taxa at the species level. Among the characters studied here, the sculpturing type is important to identify certain taxa of $P$. sect. Cephalophilon. Moreover, the achene size, existence of a beak, and surface sculpturing serve to separate Koenigia taxa from $P$. sect. Cephalophilon. However, achene characters are considered insufficient if used to clarify its taxonomic delimitation at the sectional or infrasectional level as suggested in early studies because the achene characters are recurring patterns within the Persicaria. But the achene morphological data contribute to our understanding of $P$. sect. Cephalophilon. Further studies are necessary to analyze the evolutionary tendency of the achene morphology in comparison with the molecular phylogeny within the Persicaria, and to investigate potential correlations with ecological factors such as dispersal mechanisms or habitats.

\section{Acknowledgments}

We are grateful to our colleagues at Kyung Hee University and to the directors of the herbaria of K, KHUS, KUN, PE, and WU. We also thank the anonymous reviewers for their valuable comments and suggestions, which substantially improved our manuscript. This study is part of the Ph.D. dissertation of M.-J. Kong. The work was supported by grants from the Basic Science Research Program through the National Research Foundation of Korea (NRF) funded by the Ministry of Education, Sciences and Technology [Grant numbers NRF2015R1D1A1A01058462] to S.-P. Hong.

\section{Conflict of Interest}

Authors declare that there is no conflict of interest.

\section{Literature Cited}

Ayodele, A. E. and Z.-K. Zhou. 2010. Scanning electron microscopy of fruits in the West African Polygonaceae. Journal of Systematics and Evolution 48: 336-343.

Babington, C. C. 1838. IV. Descriptions of those species of Polygonum and Fagopyrum which are contained in the Indian Herbarium of J. Forbes Royle, Esq., F.L.S., \&c., late Superintendant of the H.E.I. Botanical Garden at Saharunpore, and now Professor of Materia Medica in King's College, London. Transactions of the Linnean Society of London 18: 93-119.

Barthlott, W. 1990. Scanning electron microscopy of the epidermal surface in plants. In Scanning Electron Microscopy in Taxonomy and Functional Morphology. Claugher, D. (ed.), Claredon, Oxford. Pp. 64-94.

Don, D. 1825. Prodromus Florae Nepalensis. J. Gale, Londini, 256 pp.

Freeman, C. C. and J. L. Reveal. 2005. Polygonaceae. In Flora of North America. Vol. 5. Flora of North America Editorial Committee (ed.), Oxford University Press, New York. Pp. 479601.

Galasso, G., E. Banfi, F. De Mattia, F. Grassi, S. Sgorbati and M. 
Labra. 2009. Molecular phylogeny of Polygonum L. s.l. (Polygonoideae, Polygonaceae), focusing on European taxa: preliminary results and systematic considerations based on $r b c \mathrm{~L}$ plastidial sequence data. Atti della Società italiana di scienze naturali e del Museo civico di storia naturale di Milano 150: 113-148.

Ghimire, B., G. E. Choi, M. J. Jeong, H. Lee, K. M. Lee, S. W. Son, C. H. Lee and G. U. Suh. 2016. Fruit morphology and anatomy of Persicaria chinensis (Polygonaceae). Journal of Japanese Botany 91: 218-225.

Haraldson, K. 1978. Anatomy and taxonomy in Polygonaceae subfam. Polygonoideae Meissn. emend. Jaretzky. Symbolae Botanicae Upsaliensis 22: 1-95.

Hedberg, O. 1997. The genus Koenigia L. emend. Hedberg (Polygonaceae). Botanical Journal of the Linnean Society 124: 295-330.

Hong, S.-P. 1992. Taxonomy of the genus Aconogonon (Polygonaceae) in Himalaya and adjacent regions. Symbolae Botanicae Upsalienses. Vol. 30. Uppsala University, Uppsala, 118 pp.

Kantachot, C. and P. Chantaranothai. 2011. Achene morphology of Polygonum s.l. (Polygonaceae) in Thailand. Tropical Natural History 11: 21-28.

Kantachot, C., P. Chantaranothai and D. A. Simpson. 2010. A synopsis of the genus Persicaria (Polygonaceae) in Thailand. Thai Forest Bulletin (Botany) 38: 128-149.

Kanwal, D., R. Abid and M. Qaiser. 2016. The seed atlas of Pakistan - XIV. Polygonaceae. Pakistan Journal of Botany 48: $1833-1848$.

Kim, M. H., M. Kwak, J. Song, S. J. Lee, M. J. Yoo and C. W. Park. 2001. Morphology of hairs, flowers, and achenes of Polygonum section Echinocaulon Meisn. (Polygonaceae). Korean Journal of Plant Taxonomy 31: 143-160. (in Korean)

Kim, S. T. and M. J. Donoghue. 2008. Molecular phylogeny of Persicaria (Persicarieae, Polygonaceae). Systematic Botany 33: 77-86.

Lamb Frye, A. S. and K. A. Kron. 2003. rbcL Phylogeny and character evolution in Polygonaceae. Systematic Botany 28: 326332.

Li, A. J., T. Kao, Z. Mao and Y. Liu. 1998. Polygonaceae. In Flora Republicae Popularis Sinicae. Vol. 25(1). Li, A. J. (ed.), Science Press, Beijing. Pp. 1-209.

Li, A. J., B. Bao, A. E. Grabovskava-Borodina, S. P. Hong, J. McNeill, S. L. Mosyakin, H. Ohba and C. W. Park. 2003. Polygonaceae. In Flora of China. Vol. 5. Ulmaceae-Basellaceae. Wu, Z. Y., P. H. Raven and D. Y. Hong (eds.), Science Press, Beijing and Missouri Botanical Garden Press, St. Louis, MO. Pp. 277-350.
Lindley, J. 1838. Edwards's Botanical Register. James Ridgway, London, Pp. 62-63.

Martin, A. C. 1954. Identifying Polygonum seeds. The Journal of Wildlife Management 18: 514-520.

Meisner, C. F. 1832. Synopsis Polygonearum. In Plantae Asiaticae Rariores. Vol. 3. Wallich, N. (ed.), Treuttel and Würtz, London. Pp. 53-65.

Oh, I. C. and S. P. Hong. 1999. A taxonomic study of achene microstructure in the genera Polygonum L. s. str. and Polygonella Michx. (Polygoneae-Polygonaceae). Korean Journal of Plant Taxonomy 29: 123-134. (in Korean)

Olowokudejo, J. D. 1985. Scanning electron microscopy of fruits in the genus Biscutella L. (Cruciferae). Phytomorphology 35: 273-286.

Ronse Decraene, L. P. and J. R. Akeroyd. 1988. Generic limits in Polygonum and related genera (Polygonaceae) on the basis of flora characters. Botanical Journal of the Linnean Society 98 : 321-371.

Ronse Decraene, L. P., S. P. Hong and E. Smets. 2000. Systematic significance of fruit morphology and anatomy in tribes Persicarieae and Polygoneae (Polygonaceae). Botanical Journal of the Linnean Society 134: 301-337.

Roth, I. 1977. Fruits of Angiosperms. Gebrüder Borntraeger, Berlin, $675 \mathrm{pp}$.

Schuster, T. M., J. L. Reveal, M. J. Bayly and K. A. Kron. 2015. An updated molecular phylogeny of Polygonoideae (Polygonaceae): relationships of Oxygonum, Pteroxygonum, and Rumex, and a new circumscription of Koenigia. Taxon 64: 1188-1208.

Sojâk, J. 1974. Observations on the genus Truelleum Houtt. (Polygonaceae). Preslia 46: 139-156.

Spach, M. E. 1841. Histoire Naturelle des Vegetaux-Phanerogames. Librarie Encylopedique De Port, Paris.

Thiers, B. 2018. [continuously updated] Index Herbariorum: a global directory of public herbaria and associated staff. Retrieved Sep. 1, 2018, available from http://sweetgum.nybg.org/ih/.

Yurtseva, O. V. 2001. Ultrasculpture of achene surface in Polygonum section Polygonum (Polygonaceae) in Russia. Nordic Journal of Botany 21: 513-528.

Zhang, Z.-Y., D.-Z. Yang, A.-M. Lu and S. Knapp. 2005. Seed morphology of the tribe Hyoscyameae (Solanaceae). Taxon 54: 71-83.

Zhu, L.-T., F.-J. Lu, Y.-T. Hou and F.-Z. Li. 2007. Micro-morphology of leaf epidermis and its taxonomic significance of Polygonum section Cephalophilon in China. Journal of Wuhan Botanical Research 25: 136-142. 
Appendix 1. Specimens examined for the comparative study of achene morphology of Persicaria sect. Cephalophilon and related taxa.

\begin{tabular}{|c|c|}
\hline Taxa & Specimen information \\
\hline Persicaria capitata (Buch.-Ham. ex D. Don) H. Gross 1 & China Sichuan, Sep 1988, Expedition to Sichuan 268 (K) \\
\hline P. capitata (Buch.-Ham. ex D. Don) H. Gross 2 & Bhutan Tashigang, Jun 1979, Grierson and Long 2061 (K) \\
\hline P. capitata (Buch.-Ham. ex D. Don) H. Gross 3 & Bhutan Tschilingor, Jun 1979, Grierson and Long 2276 (K) \\
\hline P. capitata (Buch.-Ham. ex D. Don) H. Gross 4 & New Zealand Waitemata Country, Sep 1946, Bangerter 5316 (K) \\
\hline P. chinensis (L.) H. Gross var. chinensis 1 & Japan, -, Togash 533 (WU) \\
\hline P. chinensis (L.) H. Gross var. chinensis 2 & Himalaya, Sep 1977, Schilling s.n. (K) \\
\hline P. chinensis var. hispida (Hook.f.) Kantachot 1 & Thailand Phukrandung, Dec 1971, van Beuseko et al. 4512 (K) \\
\hline P. chinensis var. hispida (Hook. f.) Kantachot 2 & China Yunnan, Oct 1999, Zhou et al. 017 (PE) \\
\hline P. chinensis var. ovalifolia (Meisn.) Hara & Indonesia Sumatra, Sep 1971, Iwatsuki et al. S1493 (K) \\
\hline P. chinensis var. paradoxa (H. Lév.) B. Li 1 & China Yunnan, Oct 1940, Qin 25317 (PE) \\
\hline P. chinensis var. paradoxa (H. Lév.) B. Li 2 & China Yunnan, Nov 2002, Li et al. 1192 (KUN) \\
\hline P. glacialis (Meisn.) H. Hara var. glacialis 1 & China Yunnan, Aug 1935, Wang 69071 (PE) \\
\hline P. glacialis (Meisn.) H. Hara var. glacialis 2 & China Sichuan, Aug 2005, Boufford et al. 34635 (KUN) \\
\hline P. glacialis (Meisn.) H. Hara var. glacialis 3 & -, Handel-Mazzetti 7087 (WU) \\
\hline $\begin{array}{l}\text { P. glacialis var. przewalskii (A. K. Skvortsov \& Borodina) M. J. } \\
\text { Kong and S. P. Hong (nom. ined.) } 1\end{array}$ & China Shaanxi, Sep 1958, Xiao 738 (PE) \\
\hline $\begin{array}{l}\text { P. glacialis var. przewalskii (A. K. Skvortsov \& Borodina) M. J. } \\
\text { Kong and S. P. Hong (nom. ined.) } 2\end{array}$ & China Yunnan, Sep 1986, Sun and Qian 715 (KUN) \\
\hline P. humilis (Meisn.) H. Hara 1 & -, Sep 1875, Gamble s.n. (K) \\
\hline P. humilis (Meisn.) H. Hara 2 & China Poshang, Sep 1938, Yu 18038 (KUN) \\
\hline P. humilis (Meisn.) H. Hara 3 & China Yunnan, Aug 2008, Peng et al. 9347 (KUN) \\
\hline P. microcephala (D. Don) H. Gross var. microcephala & Bhutan Sarbhang, Mar 1982, Grierson and Long 3874 (K) \\
\hline P. microcephala var. sphaerocephala (Wall. ex Meisn.) Hara & India Chennai, May 1889, Gamble 20727 (K) \\
\hline P. microcephala var. wallichii (Meisn.) Hara & $\begin{array}{l}\text { Tibet Autonomous Region, Jun 1975, Qinghai-Xizang Expedition } 6676 \\
\text { (PE) }\end{array}$ \\
\hline P. nepalensis (Meisn.) H. Gross 1 & R.O.K. Gyeonggi-do, Sep 2011, Kong 7 (KHUS) \\
\hline P. nepalensis (Meisn.) H. Gross 2 & China Sichuan, Jul 1989, Zhao 186 (K) \\
\hline P. nepalensis (Meisn.) H. Gross 3 & Indonesia Java, Feb 1926, Danser s.n. (K) \\
\hline P. palmata (Dunn) Yonekura \& H. Ohash & China Yunnan, Oct 1936, Wang 79687 (PE) \\
\hline P. runcinata (Buch.-Ham. ex D. Don) H. Gross var. runcinata & Indonesia Papua, Aug 1998, Johns et al. 9642 (K) \\
\hline P. runcinata var. sinensis (Hemsley) B. Li & China Yunnan, Aug 1995, Li and Huang 2849 (KUN) \\
\hline P. sinuata (Royle ex Bab.) Rajbh. \& R. Joshi & Indonesia Kumaon, -, Strachey and Winterbottom 40 (K) \\
\hline P. strindbergii (J. Schust.) Galasso & China Yunnan, -, Henry 10499A (K) \\
\hline Koenigia delicatula (Meisn.) H. Hara & China Yunnan, Aug 1935, Wang 68561 (PE) \\
\hline K. nepalensis D. Don 1 & Tibet Yatung, 1897, Hobson s.n. (K) \\
\hline K. nepalensis D. Don 2 & Bhutan, Sep 1984, Sinclair and Long 5041 (K) \\
\hline K. pilosa Maxim. & China Sichuan, Jul 1989, Zhao 259 (K) \\
\hline K. islandica $\mathrm{L}$. &,- Sep $1876,-(\mathrm{K})$ \\
\hline
\end{tabular}

Herbarium acronyms are in accordance with Thiers (2018) [continuously updated].

- , no detailed collect information. 